\title{
CUATRO POETAS HISPANOAMERICANOS \\ ENTRE EL MODERNISMO Y LA VANGUARDIA
}

\author{
POR \\ ALLEN W. PHILLIPS \\ San Diego, California
}

\begin{abstract}
Hoy las literaturas de lengua española han traspuesto sus límites geográficos y merecen interés y respeto; esto es obra del modernismo. No, acaso, de los libros que fueron expresión de esta escuela, pero sí del impulso que ella dio a las letras españolas y americanas. Hasta la reacción contra el modernismo, que se observa a partir del mil novecientos veintitantos, es consecuencia o parte del modernismo, y continúa su ímpetu, transformándolo.
\end{abstract}

Jorge LuIs Borges

Hace poco, la costumbre fue hablar de los precursores del modernismo. Afortunadamente, debido a los estudios de revaloración, ha sido corregido ese error, porque se descubre que los mal llamados precursores eran, en realidad, los primeros modernistas. Unos veinticinco años después, agotada en algunos de sus aspectos más visibles la aventura modernista, se perfila otra época de transición, ahora entre el último modernismo y el primer vanguardismo. Vuelve a surgir un periodo de tanteo y de cambio, así como de indecisión, y algunos poetas oscilan entre posiciones tradicionales $u$ otras más avanzadas. Las fechas fluctúan y, dada la fluidez de las tendencias literarias, son solamente aproximadas. Sin mayores precisiones, varios críticos suelen hablar de posmodernismo para referirse a una breve etapa histórica de duración indeterminada, que abarca las postrimerías del modernismo y los comienzos tímidos del vanguardismo. Otros prefieren reconocer exclusivamente modernismo y vanguardia en el desarrollo de la poesía hispanoamericana del siglo xx. Para José Emilio Pacheco, el término posmodernismo no tiene sentido, porque ha sido refutada la creencia de que las maneras de Prosas profanas eran todo el modernis- 
mo, un movimiento desde luego mucho más amplio ${ }^{1}$. Hay evidentemente una época de transición, durante la cual parecen formularse ciertos cambios estéticos posteriores al auge modernista. Unos poetas, los más atrevidos, salen del modernismo y avanzan resueltamente hacia nuevas actitudes artísticas. En todo caso, los estudiosos no se han ocupado lo suficiente en caracterizar ese momento, de límites no bien definidos, entre los últimos rescoldos del modernismo y los comienzos de la vanguardia ${ }^{2}$.

Quisiera, por tanto, acercarme a la poesía de cuatro poetas, cuyas obras más importantes se publicaron hacia aquellos años de transición, con el objeto de demostrar sus estrechas relaciones con la lírica inmediatamente posterior. Se trata de dos escritores rioplatenses (Lugones y Herrera y Reissig) y de dos mexicanos (Ramón López Velarde y José Juan Tablada), separados de modo geográfico, pero unidos por un concepto revolucionario del arte y el deseo de rejuvenecerse. Cada uno de los poetas señalados preludia en cierto sentido la vanguardia, preparando así el terreno para lo que vendrá después y elaborando un estilo que anticipa algunas premisas fundamentales de las teorías más avanzadas. Abren caminos y ensanchan fronteras, $y$, a pesar de la agresividad vanguardista, creo ver en esa época, más que una ruptura violenta, cierta continuidad, que hace innecesaria la confrontación antagónica de dos estéticas. No niego, por supuesto, que en la segunda década del siglo xx se vociferaba mucho contra un rubendarismo caduco e inútil.

Algo parece evidento: cuando se inició el movimiento modernista en el decenio de los 1880 , no se rechazó por completo el profundo substrato de un romanticismo esencial. Otro tanto sucede después: el vanguardismo tampoco niega del todo una tradición vitalizadora y fecunda derivada del modernismo. Por iconoclastas y rebeldes que fueran los primeros vanguardistas, pienso que un estudio de las postrimerías del modernismo revelaría una evolución progresiva, lo cual no implica de ninguna manera impugnar la conquista de nuevos temas y nuevas técnicas. Los extremismos negativos son muy visibles dentro del furor antimodernista, pero en esa reacción los escritores, a mi juicio, se oponían a la prolongación de un rubendarismo agonizante y a la proliferación de fórmulas muertas continuadas por los imitadores del maestro.

${ }^{1}$ José Emilio Pacheco, Poesía modernista. Una antología general (México, 1982), p. 233.

${ }^{2}$ Una notable excepción: Saúl Yurkievich, Celebración del modernismo (BarceIona, 1976). En ese pequeño libro, su autor, tras algunos planteamientos iniciales, estudia a Darío, Lugones y Herrera puntualizando ciertas modalidades que los aproximan a la poesía posterior. Inevitables son aquí algunas concomitancias y ligeras discrepancias con el crítico argentino, fino lector de poesía moderna. 
Una premisa de las presentes páginas, entonces, es que se ha exagerado el antagonismo en aquellos años de transición, sin tener en cuenta un hecho incontrovertible: muchos de los grandes poetas contemporáneos se iniciaron precisamente dentro de la tradición modernista. Vallejo, Huidobro, Neruda y Borges en América; Antonio Machado y Juan Ramón Jiménez en España. Es decir, se nutrían de lo más valioso de esa herencia, para luego abrazar otro lenguaje y otro estilo más personal. Es verdad que algunos vanguardistas militantes parodiaban y se burlaban de Darío y Lugones, pero, en su afán de independizarse, pretendían seguir otros caminos sin despreciar en el fondo a los maestros a quienes combatían. La presencia de Darío en todos es inevitable y los testimonios son abundantes $^{3}$. Esa es la realidad literaria de aquellos años turbulentos: hasta los que más querían repudiar el modernismo no podían desligarse de su benéfica influencia, lo que no quiere decir que las princesas y las marquesas de antaño hayan continuado como las musas predilectas de los poetas ${ }^{4}$.

Nuestro anunciado propósito es precisar algunos elementos que en el proceso evolutivo y renovador vinculan a los más atrevidos modernistas con la nueva estética de vanguardia. La obra de los cuatro poetas escogidos es, a mi modo de ver, un puente que tiende a unir dos períodos históricos, diferentes entre sí, pero indisolubles de alguna manera. Lugones y Herrera son los poetas más intrépidos del modernismo; con López Velarde culmina el proceso modernista; y Tablada, aunque formado en el pleno modernismo, es, desde luego, un escritor de múltiples maneras, que lo colocan siempre entre las avanzadas.

${ }^{3}$ Por ejemplo, escribe Borges: «... Todo lo renovó Darío: la materia, el vocabulario, la métrica, la magia peculiar de ciertas palabras, la sensibilidad del poeta y de sus lectores. Su labor no ha cesado y no cesará; quienes alguna vez lo combatimos, comprendemos hoy que lo continuamos. Le podemos llamar el Libertador.» «Mensaje en honor de Rubén Darío», en Estudios sobre Rubén Dario, ed. de Ernesto Mejía Sánchez (México, 1968), p. 13. Y en otro lugar (Prólogo, «El oro de los tigres», en Obras completas [Buenos Aires, 1974]) declara Borges categóricamente que sus versos proceden del modernismo (p. 1081).

${ }^{4}$ Con argumentación convincente y textos incontrovertibles, el ejemplar artículo de Raimundo Lida «Desde Rubén (Apuntes y antología)» (Asomante, XXIII, núm. 2 [1967], pp. 7-21) traza esa extraordinaria permanencia y perduración de Darío en los poetas de lengua española.

Nuevamente quisiera recordar el discurso al alimón de García Lorca y Neruda en honor de Darío, que tuvo lugar en Buenos Aires en 1934. 
VISTAZO H ISTÓRICO: $1905-1930^{5}$

Por supuesto, las corrientes literarias no ajustan su aparición, vigencia y descenso a una precisa esquematización cronológica. Sin embargo, en esa época de transición, superados algunos elementos epidérmicos del modernismo, fueron publicados ciertos libros, que señalaron un cambio definitivo en los temas y en el lenguaje poético. Exhumándose a sí mismo, Darío publicó su último gran libro de versos, El canto errante, en 1907 (no olvidemos su Prólogo dirigido «A los nuevos poetas de las Españas», así como la inclusión en el mismo volumen de la sorprendente «Epístola» y algún poema más de resonancias modernas), aunque después escribe, desde luego, poemas de gran calidad. Varios poetas de alta categoría formados en el modernismo, prácticamente se inmovilizaron o prolongaron sin grandes novedades la tradición (González Martínez, Díaz Mirón, Nervo, Rebolledo, Valencia, Jaimes Freyre), mientras que otros, los más osados, se lanzaron a nuevas aventuras. Antes de consagrarse casi enteramente a la tradición y a la patria, cada nuevo libro de Lugones representaba una renovación, característica de su gran versatilidad. E1 Lunario sentimental (1909), único libro que nos concierne directamente aquí, prefigura sin duda todo el proceso del ultraísmo argentino, si hemos de creer a Borges ${ }^{6}$. Julio Herrera y Reissig, en muy poco tiempo, deslumbró a los lectores con las audacias metafóricas de los sonetos de Los éxtasis de la montaña (1904-1907) y de su delirante e incoherente «Tertulia lunática» (1909). De modo especial, Herrera, más que Lugones, influyó en los primeros poemas de Vallejo y de Neruda. Pronto publicará José María Eguren la poesía hermética de Simbólicas (1911) y La canción de las figuras (1916), añadiendo nuevas notas esotéricas a la poesía hispanoamericana de entonces. En la Argentina, Baldomero Fernández Moreno, abanderado del sencillismo, comienza su obra poética con Las iniciales del mismal (1915), y cantó los temas vernáculos a su alrededor, exaltando el valor afectivo de lo humilde y lo vulgar. Otros poetas en distintas latitudes (Carriego, Luis Carlos López) cultivaron un criollismo literario. En el Perú, por ejemplo, hacia los mismos años, Abraham Valdelomar, espíritu inquieto, va en búsqueda de una nueva modalidad poética, y en ella tiende a abandonar su esteticismo inicial para cultivar, a su vez, temas más cotidianos (la vida familiar, la provincia). Su aristocracia se funde con lo nativista, tra-

${ }^{5}$ Acompaño a José Olivio Jiménez cuando afirma en su Antología de la poesía hispanoamericana contemporánea (1914-1970) (Madrid, 1971) que en la década de 1920 a 1930 aparece una expresión poética diferente a la del modernismo (p. 14).

' Jorge Luis Borges, Leopoldo Lugones (Buenos Aires, 1955), pp. 78-79. 
tado con voluntad de estilo, y hasta en momentos aislados («Luna Park») parece anticipar la poesía posterior.

En México, Ramón López Velarde sale definitivamente del modernismo por la puerta de un decoroso nacionalismo y la creación de un insólito lenguaje poético. Profundamente influido por el magisterio de Lugones (en menor grado por Herrera, a quien también admiraba), publica su breve e intensa obra ${ }^{7}$. La sangre devota ve la luz en 1916 y, tres años después, algunos de sus mejores poemas se recogen en un segundo volumen titulado Zozobra (1919), libro de la consagración definitiva, después de haber descubierto anteriormente en su libro primigenio el fondo lírico de la provincia mexicana. Otras poesías de subido valor, inclusive «La suave patria», y sus excelentes prosas poemáticas fueron editadas póstumamente. José Juan Tablada, amigo del más joven López Velarde ${ }^{8}$ y centro activo de la Revista Moderna por mucho tiempo, abandona, tras la publicación de El florilegio (1899, 1904), su más visible herencia modernista e inicia una poesía de tipo diferente, dando a la estampa tres libros singulares: Un día... poemas sintéticos (1919), Li-Po y otros poemas (1920) y El jarro de flores. Disociaciones líricas (1922). Su obra poética posterior (La feria, 1928), de muy acendrado y brillante mexicanismo, nos interesa menos en el presente contexto ${ }^{9}$.

Para estas fechas estamos ya en los umbrales de la poesía contemporánea, y se hacen menos claros los esquemas ordenadores. Vallejo publica Los heraldos negros (1918), libro casi simultáneo con La sangre devota; es obra de un joven poeta en busca de su verdadera voz, en la cual se mezclan poemas todavía modernistas con otros que revelan ya su originalidad radical. Pronto aparecerá la primera edición de Trilce (1922) y se realiza la transformación total. Hacia mediados de la segunda década del siglo está ya en plena e intensa actividad poética y teórica Vicente Huidobro, que publica entre 1916 y 1918 varias obras importantes; colabora con textos novedosos en Nord-Sur (1917); ha estado ya en París y en Madrid (1917-1918), y en 1919 regresa a Europa con la primera versión de Altazor, que no se publica en su forma definitiva sino hasta 1931. El

${ }^{7}$ El texto más significativo de López Velarde sobre Lugones es el siguiente: «La corona y el cetro de Lugones», en Obras (México, 1979), pp. 478-481.

${ }^{8}$ Véase mi artículo «Una amistad literaria: Tablada y López Velarde», en $N R F H$, $\mathrm{XV}$, núms. 3-4 (1961), pp. 605-616, luego recogido en Estudios y notas sobre literaiura hispanoamericana (México, 1965), pp. 107-120.

${ }^{9}$ Tablada anunciaba con frecuencia la publicación de otro libro de poemas inspirados en sus preocupaciones espiritistas y sus estudios teosóficos con el título de Intersecciones. Esta porción de su obra, sin ordenar y de índole miscelánea, puede leerse ahora en sus Obras. Poesía, I (México, 1971), pp. 531-613. 
joven Pablo Neruda da a luz su segundo poemario, Crepusculario («se mezclaron voces ajenas a las mías»), y al año siguiente (1924), su primer libro personal Veinte poemas de amor y una canción desesperada. De 1926 es Tentativa del hombre infinito, y solamente ahora es definitiva la ruptura. Con otro título de los mismos años puede cerrarse este breve recorrido histórico: de Borges aparece en 1923 Fervor de Buenos Aires. $Y$ finalmente añadimos que en 1925 José Ortega y Gasset publica su ensayo «Deshumanización del arte», brillante análisis y pronóstico de toda una época de vanguardia, así como apología del antirrealismo en el arte.

Nadie pone en duda la actitud sumamente agresiva e iconoclasta de los ismos que proliferaron en la época de posguerra. Revolución y libertad. Liberarse de un concepto tradicional de la belleza y de un lenguaje caduco fue el signo de los tiempos cuando empezaron a cundir las proclamas vanguardistas. ¡Abajo todos los convencionalismos formales y temáticos! Por encima de todo, se entroniza la imagen insólita y audaz, que resiste y supera la lógica conceptual. Se incorpora a la poesía un lenguaje intencionadamente prosaico, tomado de las lenguas de la ciudad moderna y cosmopolita. Y otra conquista: el verso libre, hasta sin rima, y, por tanto, nuevos ritmos poéticos. En los inicios del vanguardismo se acentúan el negativismo y la incoherencia. Luego, los mejores poetas salen de los ismos subversivos para hacer una obra más constructiva; se dan cuenta de que, a su pesar, han creado otra retórica. Sin que deje de ser aventura, se impone ahora orden y la poesía se hace más trascendente. Pronto se darán dos direcciones fundamentales en los próximos pasos evolutivos de la lírica contemporánea de Hispanoamérica: la poesía pura y el superrealismo.

\title{
LEOPOLDO LUGONES
}

\begin{abstract}
.. como el verso vive de la metáfora, es decir, de la analogía pintoresca de las cosas entre sí, necesita frases nuevas para exponer dichas analogías, si es original como debe (L. Lugones, «Prólogo» a Lunario sentimental).
\end{abstract}

El deslumbrante Lunario sentimental es un seguro anticipo del vanguardismo continental y naturalmente del ultraísmo argentino. Término del modernismo: ruptura y superación. Altas autoridades confirman ese hecho histórico. Ya señalamos que Borges reconoce ahora el papel precursor del libro de 1909, y proclama que su propia generación son «involuntarios y fatales alumnos» o continuadores del Lunario, «inconfesado ar- 
quetipo de toda la poesía profesionalmente nueva del continente» ${ }^{10}$. Por su parte, Alfonso Reyes advierte en una nota necrológica que en el Lunario estaba «el semillero de toda la nueva poesía argentina» ${ }^{11}$. Nacido en el modernismo, Lugones se sale de las escuelas, según Reyes, por su fuerte personalidad artística y se desclasifica palpablemente con la publicación de cada nuevo libro. El poeta argentino, en continua evolución, no se inmoviliza, sino que su poesía se transformará una y otra vez, y todos los libros de versos de Lugones «... son una constante conclusión y apertura, al mismo tiempo» ${ }^{12}$. Una vez, Valle-Inclán, cuya obra del segundo período revela estrecho parentesco con ciertas maneras lugonianas ${ }^{13}$, sostuvo que el poeta americano había agotado las posibilidades del modernismo, dejándolo prácticamente exhausto de sentido, y que después de la experiencia lugoniana urgía cambiar de orientación estética, y añade luego unas consideraciones perspicaces: «De todos modos, la poesía de su compatriota de usted (habla con Francisco Luis Bernárdez) es, como mensaje humano, muy inferior a la del fundador de la escuela. La voz de Darío busca siempre un interlocutor. Aspira al diálogo. La de Lugones parece contentarse con el hermoso eco de su propio sonido. No quiere salir del monólogo» ${ }^{14}$. Siempre la crítica ha notado la falta de verdadero lirismo e intimidad en la obra de Lugones. El styo es un talento más bien descriptivo y narrativo. Muchas veces se ha repetido que queda lejos de su verso y que no sabe establecer un vínculo afectivo con el lector, quien admira más que otra cosa el virtuosismo revelado en la elaboración de un objeto artístico. Es decir, en la obra de Lugones, los instantes tiernos o emotivos son muy contados. A veces los encubre y los desvía hacia otro plano con desplantes o salidas humoristas.

Lugones, junto con Valle en los tiempos modernos, continúa la tradición de Quevedo y de Goya. Prodigioso renovador de la lengua y temperamento satírico, busca la originalidad huyendo del lugar común. Es sencillamente, como cree Borges, un genio verbal, lo cual supone también sus riesgos ${ }^{15}$. La trayectoria de Lugones como poeta es larga, y llena unos cuarenta años desde la publicación de los versos enfáticos de Las montañas

${ }^{10}$ Borges, Leopoldo Lugones, pp. 78 y 83.

${ }^{11}$ Alfonso Reyes, Obras completas, vol. XII (México, 1960), p. 147.

${ }_{12}$ Ezequiel Martínez Estrada, Leopoldo Lugones, retrato sin retocar (Buenos Aires, 1968), pp. 107-108.

${ }^{3}$ Véase mi trabajo "Notas para un estudio comparativo de Lugones y ValleInclán (Lunario sentimental y La pipa de Kif)», en Boletin de la Biblioteca de Menéndez Pelayo, LVI, núms. 1-4 (enero-diciembre 1980), pp. 317-345.

${ }^{14}$ Francisco Luis Bernárdez, "Valle-Inclán en la Puebla del Caramiñal», en Mundo de las Españas (Buenos Aires, 1967), pp. 62.

${ }^{15}$ Borges, Leopoldo Lugones, pp. 9-11 y 94-95. 
del oro (1897). Puesto que me interesa principalmente aquí un solo libro, basta decir que después de la publicación del Lunario la poesía de Lugones se vuelve más nacionalista y tradicional, inspirándose en los personajes' y la naturaleza de la patria. En admirable síntesis, escribe Picón Salas ${ }^{16}$ :

... acaso más que poeta lírico fue siempre un poeta épico, extraviado en un tiempo de decadencia de las epopeyas. Acaso el mundo exterior, el escenario de la naturaleza, le dijo siempre más que las legítimas angustias del hombre... Lugones se refugia en un arte objetivo, en el gran ciclo naturalista y tradicional que comienza en las Odas seculares y concluye en los Romances de Río Seco. Hay siempre el tema amoroso, el refinamiento crepuscular de ciertos poemas...; pero más que pasión es virtuosismo; más que misterio poético, alarde metafórico. Lo descriptivo parece congelar en él la congoja humana.

Algo más, sin embargo, tiene que decirse de Los crepúsculos del jardín (1905), el libro más convencionalmente modernista de cuantos escribió Lugones. Lo que más resalta en esta segunda colección de sus versos, tradicionalmente bellos, es que encierran una retórica de amor derivada de consabidos modelos literarios. Es poesía simbolista, vaga y lánguida, que recrea estados de alma. Los hermosos y artificiosos sonetos de «Los doce gozos» son dignos de antología y confirman el evidente parentesco con Herrera y Reissig al fundirse el paisaje impresionista y el erotismo. Pero hay algo más en el libro. Una tendencia realista y menos suntuosa: el conmovedor poema de «El solterón» y la composición criollista de «Emoción aldeana", cuyos versos irregulares se nutren de prosaísmos intencionados. Ambos poemas preludian otros derroteros explotados luego por Lugones, y precisamente esa visión exacta e irreverente de la realidad, en sus aspectos más triviales, es lo que caracterizará el subversivo Lunario. Cabe añadir que una deliciosa tonalidad ligera matiza «E1 prefacio» y la burlona poesía «A tus imperfecciones».

En breve sintesis, ¿qué decir del audaz y desconcertante Lunario? En primer lugar, la grandilocuencia declamadora y los decadentismos librescos han sido abandonados. Lugones, además, se olvida del mero sensualismo erótico y los ambientes impresionistas al cultivar la poesía de la ciudad. El autor se muestra como agudo observador de la realidad cotidiana y a menudo trivial de todos los días. Percibe el lado más displicente $\mathrm{y}^{\prime}$ grotesco de las cosas; toma conciencia de las incongruencias de la vida

${ }^{16}$ Mariano Picón-Salas, «Lugones, un gran argentino», en Obras selectas (Madrid, 1953), p. 570. 
e ironiza sobre ellas. Y, mediante un punzante humor, a veces de gusto dudoso, desmitifica y despoetiza los elementos tradicionalmente considerados más aptos para la lírica. No sin cierta agresividad se representa el lado negativo de los seres y los objetos, lo cual lleva indefectiblemente a una modalidad caricaturesca. Así se someten a burla los valores más sagrados, y, en más de una ocasión, esa poesía parece ser parodia del modernismo y de sus bellos tópicos. El tono es fundamentalmente sarcástico y socarrón; se inicia la adoración irónica de la luna, desvalorizada y echada a rodar por las calles de Buenos Aires ${ }^{17}$. El libro no conmueve, pero sí divierte, y el autor se evade del mundo «sentimental» por el camino de la ironía y la burla. Es, finalmente, un libro ingenioso, lleno de sorprendentes pirotecnias verbales, de rima y de vocabulario.

El Prólogo es doctrinal y programático. No sólo se da primacía a la metáfora, como se ve en el epígrafe citado, sino que insiste Lugones en que la tarea del escritor es enriquecer el idioma, y para realizar ese afán de renovación, encontrar imágenes nuevas es la obligación del poeta. Al hablar de las analogías pintorescas entre las cosas, esta palabra da una clave para entrar en el mundo extravagante y abigarrado del Lunario. Obviamente, Lugones, en la teoría y en la práctica, prefigura el culto vanguardista de la metáfora. También en el Prólogo habla del verso libre, utilizado tan a menudo en el libro, pero más tarde polemiza con los poetas jóvenes porque cree en la rima como elemento esencial del verso moderno, algo juzgado inútil por los vanguardistas.

Si Darío es uno de los primeros en fundir y mezclar los prosaísmos de la vida contemporánea con un lenguaje tradicionalmente bello y poético, Lugones va mucho más lejos en esa dirección típica de la poesía más moderna. Practica una especie de sabotaje al unir con lo prosaico una visión bella de la realidad. Tampoco rehúye los feísmos, y aprovecha un vocabulario derivado de las más extrañas fuentes: lo técnico, lo familiar, lo matemático y especialmente de todas las ciencias. Al contarnos «las

${ }^{17}$ No se puede eliminar el recuerdo de Laforgue en ese contexto. Sobre este aspecto del libro, véase mi ensayo «Novedad y lenguaje en tres poetas: Laforgue, Lugones y López Velarde», en El simbolismo, ed. de José Olivio Jiménez (Madrid, 1979), pp. 198-230. Sobre el mismo tema son estas palabras de Octavio Paz (El arco y la lira, 2. ${ }^{2}$ ed. [México, 1967]): «... Es Laforgue, pero un Laforgue desmesurado, con menos corazón y más ojos y en el que la ironía ha crecido hasta volverse visión descomunal y grotesta... El mexicano López Velarde recoge y transforma la estética inhumana de Lugones. Es el primero que de verdad oye hablar a la gente y que percibe en ese murmullo confuso el oleaje del ritmo, la música del tiempo...» (p. 95). Para una tentativa de balance sobre el siempre discutido y discutible libro de Lugones, véase Alfredo A. Roggiano, "Qué y qué no del Lunario sentimental», en Revista Iberoamericana, núm. 94 (enero-marzo 1976), pp. 71-77. 
cosas singulares de la luna» y de sus clientes más asiduos (la rentista, la nodriza, el sastre, el poeta-vate, las doncellas y solteronas del suburbio) suele someter su galería de personas, burguesas en su mayoría, a una desvalorización grotesca, y no resisto la tentación de recordar algunos animales que también figuran entre esos amigos de la luz lunar: el búho con ojos de caldo, los lobos de agudos rostros judiciales y la oblicua hiena. Todos los procedimientos mencionados pueden ejemplificarse fácilmente en determinados poemas del volumen: siempre en el osado "Himno a la Luna», poema que da la tónica al libro entero, y luego en "Los fuegos artificiales», «Un trozo de senología», «El taller de la luna», «Divagación lunar» y algunos más. Resumiendo: poesía jovial y festiva, de tono irreverente y coloquial, que se nutre de una generosa abundancia de imágenes pintorescas y de un léxico inagotable.

\section{Julio Herrera y Reissig}

En el verso culto, las palabras tienen dos almas: una de armonía y otra ideológica. De su combinación, que ondula un ritmo doble, fluye un residuo emocional ... el principal valor de la literatura ... consiste no en lo que dice, sino en lo que sugiere y hace pensar. El gran Arte es el arte evocador, el arte emocional, que obra por sugestión, el que necesita, para ser sentido, de un receptor armonioso que sea un alma instrumentada y un clavicordio que sea un hombre (J. Herrera y Reissig, "Psicología literaria»).

Julio Herrera y Reissig ya no es un poeta tan desconocido como hace algunos años, aunque ciertas leyendas sobre su persona se perpetúan desvirtuando su modo de ser. No me interesan por ahora esos tópicos, porque sencillamente quisiera situar al poeta de temperamento originalísimo y rápida evolución en el movimiento modernista, al cual dio unas notas muy personales, y luego intentar de explicar su fortuna posterior entre los escritores más jóvenes que él.

Herrera y Reissig fue un excesivo que lo radicalizaba todo, pagando tributo a las modas de la época, y su potencia verbal desborda los cauces normales de la lengua. La exuberancia de su numen sin duda da origen a unos desniveles, y también esa misma exuberancia suele conducir a largas e inconexas enumeraciones de los seres y cosas más disímiles. Muerto en 1910, sin embargo, no pudo presenciar las transformaciones que conocieron Lugones, Tablada y López Velarde. Antes que nada, dos hechos significativos, de tipo histórico, merecen tenerse en cuenta en el presente contexto. Cuando Guillermo de Torre preparaba sus Literaturas europeas 
de vanguardia (Madrid, 1925), incluyó en el libro unas páginas (114-124) sobre Herrera, «genial e incógnito precursor» del creacionismo de Huidobro, destacando en su obra «un conjunto de imágenes del más puro y novísimo lirismo» (p. 119). No importa que hayan sido eliminadas esas páginas años después cuando el cronista se convierte en historiador al redactar su monumental Historia de las literaturas de vanguardia (Madrid, 1965). Constituyen un signo de los tiempos juveniles, y correspondían a los fines polémicos del día. También me gustaría recordar un segundo dato que tiende a confirmar la presencia de Herrera en los gustos de los poetas modernos. E1 número 5 de la revista Caballo verde para la poesía (1936), dirigida en España por Pablo Neruda, fue dedicado íntegramente a un homenaje al poeta uruguayo, pero no llegó a ser distribuida esa entrega por el levantamiento franquista y el comienzo de la guerra civil.

La crítica ha diferenciado siempre dos líneas fundamentales en la lírica de Herrera y Reassig. La primera fase es la pastoral, de églogas idílicas y cuadros rurales, llenos de paz y serenidad. La poesía de esta primera modalidad, sencilla y equilibrada, se da de manera especial en dos poemas narrativos de extraordinaria belleza («Ciles alucinada», 1902, y «La muerte del pastor», 1907) y en las dos series de Los éxtasis de la montaña (19041907). Muy distinta es la segunda dirección. Se inicia en «La vida» (1903), largo poema de pretensiones metafísicas, y llega a su más alta tensión en «Desolación absurda» (1903) y «Tertulia lunática» (1909). En las décimas de «Desolación absurda», por ejemplo, el poeta da rienda suelta a sus visiones fantasmagóricas de un paisaje nocturno. Se oyen sonidos misteriosos; la Luna se desvaloriza y se entrega a piruetas acrobáticas, y se impone un aire de erotismo satánico. A la mujer, «hada de la neurastenia» y «mercadera de beleños», se dirige directamente el poeta: « ¡Tú eres póstuma y marchita / misteriosa flor erótica, / miliunanochesca, hipnótica, / flor de Estigia ocre y marchita; / tú eres absurda y maldita; / desterrada del Placer, / la paradoja del ser / en el borrón de la Nada, / una hurí desesperada / del harem de Baudelaire!» En «Tertulia lunática», la visión torturada y febril de Herrera se acerca a lo que podría llamarse la poesía de la subconsciencia, y se desplaza hacia los rincones más oscuros del pensamiento. Se sueñan nuevas realidades alejadas de toda lógica conceptual ( $\ll y$ es el molino una agreste / libélula embalsamada, / en un alfiler picada / a la vitrina celeste»); se expresan los mismos sentimientos ambiguos ante la mujer que lo devora todo. Poesía abstrusa y compleja, alucinante; se rompen los nexos lógicos y todo se vuelve caos y pesadilla en un mundo onírico, de valores inestables. Los siguientes versos dan la pauta: 
Las cosas se hacen facsímiles

de mis alucinaciones

y son como asociaciones

simbólicas de facsímiles...

La realidad espectral

pasa a través de la trágica

y turbia linterna mágica

de mi razón espectral...

En el vocabulario, extravagante y rico, el poeta no vacila ante ninguna palabra; se utilizan voces prosaicas y coloquiales, junto con las palabras más cultas y técnicas de la vida moderna. El poema es, por lo menos en parte, búsqueda de la propia entidad del poeta, desorientado y amenazado por las fuerzas oscuras. Según Yurkievich, esa visión desintegradora anticipa a la Residencia en la tierra de Neruda ${ }^{18}$, y para Pacheco es su poema más importante ${ }^{19}$. En fin, poesía irracional por los cuatro costados, que en más de una ocasión se acerca a los predios de lo absurdo.

Digamos algo acerca de otros aspectos de la rápida trayectoria de Herrera, cuya vida literaria dura apenas diez años. Fundamentalmente fue poeta simbolista, y representaba todo el proceso variado del movimiento modernista en sus principales vertientes estéticas. La poesía de Las pascuas del tiempo (1900) es poco original e incorpora todo un fondo opulento y versallesco; fiestas y bailes cortesanos, objetos de arte, exotismos, jugueteos verbales. En fin, la escenografía exterior de un estilo. Los poemas, a menudo se estructuran en forma de largos desfiles culturales, a los cuales no falta de cuando en cuando un esguince humorístico. Escribe después los sonetos amorosos de Los parques abandonados (1902-1908), en los cuales es muy marcada la complicidad cósmica en la presentación de los distintos matices del amor (sentimental, macabro, sádico, voluptuoso), y luego, hacia finales de su vida, se destaca otro grupo de sonetos, los atrevidos cromos exóticos de Las clepsidras. En ellos el poeta recrea mundos lejanos y sus mitos religiosos o esotéricos; los objetos de lujo y la plasticidad, así como la nota arqueológica, delatan una raíz parnasiana, pero la imagen es totalmente nueva. A veces, la construcción verbal, siempre brillante, obstaculiza el análisis, y las metáforas sibilinas desconciertan:

18 Yurkievich, op. cit., p. 84.

19 Pacheco, op. cit., p. 203. Continúa diciendo acerca de «Tertulia lunática»: «... es el gran fin de fiesta del modernismo. Nada lo describe mejor que la imagen del carnaval. El poeta disfraza todos los mitos e iconos del fin de siglo en un desfile fantasmagórico que se ríe de sí mismo, pero a la vez se toma profundamente en serio. Herrera y Reissig quema lo que el modernismo ha adorado y adora lo que ha quemado». 
Lóbrega rosa que tu almizcle efluvias

y pitonisa de epilepsias libias,

ofrendaste a Gonk-Gonk vísceras tibias

y corazones de panteras nubias.

(«Oblación abracadabra»)

Cultiva enérgicas sinestesias: «En el ritual de las metempsicosis / bramaron fulgurantes apoteosis / los clarines del Sol... («Oleo indostánico»); y su imaginación informa muchas imágenes no muy lejos de las creacionistas: "Y a modo de espectrales obsesiones, / la torva cornamenta de un molino / amenazaba las constelaciones...» («Idealidad exótica») o «Los astros tienen las mejillas tiernas...» («Génesis»).

A propósito he dejado hasta ahora un breve comentario sobre «La muerte del pastor», hermosa balada digna de los más altos elogios de Rubén Dario ${ }^{20}$, y las dos series de sonetos Los éxtasis de la montaña. Mediante una narración fragmentada, la balada cuenta o, mejor dicho, sugiere la historia secreta del destino de Armando el pastor. Los personajes se mueven en una atmósfera sonámbula e irreal, $y$, finalmente, ese triste episodio campestre alcanza una dimensión atemporal y mítica. Se trata de un portento de armonización y de narración diluída. $Y$ estamos muy cerca de un clima lorquiano por la musicalidad obsesionante de los octosílabos y el papel activo de la naturaleza, portadora del dolor humano.

Los sonetos alejandrinos de Los éxtasis merecen un estudio mucho más detenido de lo que el espacio aquí permite. Ahora el don imaginístico de Herrera se desborda en enérgicas y audaces metáforas, en algunos casos sin duda pre-creacionistas. El paisaje se desrealiza y se espiritualiza ${ }^{21}$; los poemas, de intensa emoción panteísta, recrean lo placentero y lo ingenuo de la vida rural; y el poeta demuestra una gran predilección por los momentos transitorios del día, captando el juego de luces y sombras, así como el efecto de la luz sobre las cosas. No todos los personajes pertenecen a la tradición bucólica ni se mueven según los convencionalismos pastoriles. En los retratos de ciertos personajes típicos del pueblo (el barbero, el cura, el ama, el médico, la llavera) se observa a menudo un suave y benigno humor, lejos de la ironía hiriente de Lugones, porque en el instante de la burla asoma una nota compasiva y piadosa. Hasta en un momento («Do-

${ }^{20}$ Afirma Darío: «... Este poema que el autor 1lama, con mucho tino, Balada eglógica, y que ha puesto bajo la advocación de Virgilio, es de lo más suavemente encantador, de lo más musicalmente sentimental y de lo más simplemente fino que se haya escrito en nuestra lengua...» Cito según Antología lirica de Julio Herrera y Reissig, edición de Sabat Ercasty y Manuel de Castro (Santiago, 1942), p. 41.

${ }^{21}$ Acerca de ese aspecto de la obra de Herrera, es significativa su prosa crítica «Psicología literaria», en Prosas (Montevideo, 1918), pp. 99-113. 
minus vobiscum») la vida moderna irrumpe en la placidez dominguera de la aldea, que no suele reflejar notas feístas por la visión idílica de Herrera. Por último, la crítica ya ha advertido muchas imágenes sueltas que sin duda llegaron a excitar la fantasía creadora de muchos jóvenes poetas hispanoamericanos de aquellos tiempos. Esta riqueza imaginativa se da plenamente en los sonetos «El alba», «La noche», "Las horas graves», y me permito transcribir algunos ejemplos más de metáforas atrevidas: «y el cielo campesino contempla ingenuamente / la arruga pensativa que tiene la montaña»; "Llovió. Trisca a lo lejos un sol convaleciente»; «la inocencia del día se lava en la fontana»; "Tirita entre algodones húmedos la arboleda / La cumbre está en un blanco éxtasis idealista»; «rasca un grillo el silencio perfumado de rosas». En gran parte, las energías expresivas de Herrera y Reissig pertenecen a los modos impresionistas, pero otras imágenes son de tipo expresionista, porque alcanzan un nivel ultraterrenal al extremarse la fantasía del poeta. De una manera intensa, el sentimiento de Herrera se proyecta en la realidad exterior, infundiéndole un estremecimiento lírico, y así la materia adquiere el temple del poeta ${ }^{22}$ :

Ramón López Velarde

La reducción de la vida sentimental a ecuaciones psicológicas (reducción intentada por Góngora) ha sido consumada por Lugones. El sistema poético hase convertido en sistema crítico. Quien sea incapaz de tomarse el pulso a sí mismo no pasará de borrajear prosas de pamplina y versos de cáscara... (R. López Velarde, «La corona y el cetro de Lugones»).

Con la concentrada e intensa obra de Ramón López Velarde comienza la poesía mexicana moderna. Encuentra en ella su lenguaje y es un innegable punto de partida, que no se puede repetir, según Octavio $\mathrm{Paz}^{23}$ :

${ }^{22}$ Federico de Onís (Antología de la poesía española e hispanoamericana, 2. ed. [Nueva York, 1961]) opina que Herrera aprendió mucho de Góngora (lo que es muy cierto) y que influyó en el tránsito del modernismo hacia el ultraísmo (p. 471).

Por su parte, Borges dedica al poeta unas páginas de Inquisiciones (Buenos Aires, 1925), y en ellas admite que por su generosidad metafórica algunos piensan que Herrera es precursor del creacionismo, hecho que niega: «... es el hombre que cumple largamente su diseño, no el que indica bosquejos invirtuosos que otros definirán después. Está todo él en sí, con aseidad, nunca en función de forasteras valías...» (p. 143). En el mismo texto, la hermosa metáfora de Los éxtasis de la montaña ( $Y$ palomas violetas salen como recuerdos / De las viejas paredes arrugadas y oscuras») «sirve a Borges como ejemplo de una imagen que esclarece los sucesos del mundo aparencial, traduciéndolos en hechos psicológicos» (p. 144).

${ }^{23}$ Octavio Paz, Las peras del olmo, pp. 25-26. 
... Si parte de su poesía nos parece ingenua o limitada, nada impide que veamos en ella algo que aún sus sucesores no han realizado completamente: la búsqueda, y el hallazgo, de lo universal a través de lo genuino y lo propio. La herencia de López Velarde es ardua: invención y lealtad a su tiempo y su pueblo, esto es, una universalidad que no nos traicione y una fidelidad que no nos aísle ni ahogue. Y si es cierto que no es posible regresar a la poesía de López Velarde, también lo es que ese regreso es imposible precisamente porque ella constituye nuestro único punto de partida.

En el presente contexto, vale la pena señalar nuevamente que, en una época, los estudios más valiosos sobre la obra del escritor zacatecano se debían a los poetas de la generación de los Contemporáneos, y de modo especial a Xavier Villaurrutia, el descubridor moderno de López Velarde, quien destierra la visión superficial de un poeta meramente costumbrista y católico. Sin ser discípulos, esos poetas posteriores absorbieron su música y su palabra. Eran, pues, espíritus afines. La misma admiración se prolonga en la obra crítica de Octavio Paz y José Emilio Pacheco.

En la poesía secreta y singularmente compleja de López Velarde se cierra el modernismo en México ${ }^{24}$. Desde luego, los exotismos y oropeles superfluos de un estilo han desaparecido, pero una visión más profunda del modernismo permite incluir al poeta dentro del movimiento. Oigamos los altos elogios de Pablo Neruda:

En la gran trilogía del modernismo es Ramón López Velarde el maestro final, el que pone el punto sin coma. Una época rumorosa ha terminado. Sus grandes hermanos, el caudaloso Rubén Darío y el łunático Herrera y Reissig, han abierto las puertas de una América anticuada, han hecho circular el aire libre, han llenado de cisnes los parques mutnicipales, y de impaciente sabiduría, tristeza, remordimiento, locura e inteligencia los álbumes de las señoritas...

Pero esta revolución no es completa si no consideramos este arcángel final que dio a la poesía americana un sabor y una fragancia que durará para siempre. Sus breves páginas alcanzan, de algún modo sutil, la eternidad de la poesía.

Pero al mismo tiempo que se reconoce plenamente la herencia modernista de López Velarde, hay en su poesía anticipos de formas y técnicas que se adelantan a las modalidades más características de ciertos escritores históricamente posteriores.

${ }^{24}$ José Emilio Pacheco, Antología del modernismo (México, 1970), vol. I, páginas L-LI, y vol. II, p. 128.

${ }^{25}$ Pablo Neruda, Presencia de López Velarde en Chile (Santiago, 1963), p. 25 
En La sangre devota hay ya varios poemas cuya métrica libre los acerca a la vanguardia, aunque siempre se mantiene la rima, como también la mantiene Lugones. Consignemos que en sus últimas poesías López Velarde regresa a una regularidad métrica después de haber prolongado las técnicas libérrimas en Zozobra. Otras composiciones de su primer libro de 1916 («En las tinieblas húmedas», «En la plaza de Armas», «Un lacónico grito...») también reflejan las tensiones creadas por la fusión de intencionados prosaísmos con la imagen poética. Actual es, por lo demás, la importancia dada a la metáfora, en muchos niveles de significado, y una actitud irónica ante la vida confirma su deseo de hacer algo diferente y más moderno. Ese hijo de la provincia mexicana se ha convertido, con el tiempo, en «flâneur de la Avenida Madero», según frase feliz de Pacheco ${ }^{26}$. El año clave es el de 1915, cuando escribe «Mi prima Agueda», uno de sus mejores logros de la primera época, que representa ya, al poetizar una vivencia de adolescente, un cambio linguístico y formal dentro de una atmósfera de sutil autoironía ${ }^{27}$.

Mucho debía López Velarde a Lugones («el sumo poeta») y en sus visiones barrocas el mexicano utiliza procedimientos que recuerdan seguramente el estilo lugoniano. Poemas como «Día 13», «Anima adoratriz»y, de modo especial, la jovial y pintoresca composición «Memorias del circo» no dejan lugar a dudas sobre esta herencia. Pienso también que el poeta mexicano halló en la poesía de Herrera y Reissig otra posible fuente, tal vez más lejana, para la creación de sus propias imágenes audaces. Si bien se aparta radicalmente López Velarde de la suntuosidad decorativa y de los ribetes decadentistas del uruguayo, me parece que ciertos versos de "La última odalisca» traen ineludible eco de la intensidad lingüística también propia del poeta uruguayo.

En sus importantes páginas sobre la poesía de Amado Nervo ( $\mathrm{La}$ magia de Nervo») proclama López Velarde que el mundo es mágico, y en otra parte afirma que «sólo por la corazonada nos aproximamos al acierto» («Novedad de la patria»). Es decir, como poeta no le interesan los vanos cerebralismos que estropean la emoción de las cosas. Logró trasladar así a sus versos nuevos e insospechados matices de la realidad exterior sin eliminar de ella ningún objeto, por nimio que fuera. Cree en la estética de la originalidad, «el sexo mismo del poeta» («Francisco González León»), y la verdadera originalidad poética es la de los sentidos y de las

${ }^{26}$ Pacheco, Antología del modernismo, vol. II, p. 129.

${ }^{27}$ Sobre el mismo poema, véase mis páginas «Ramón López Velarde en la poesía hispanoamericana del postmodernismo", en Cinco estudios sobre literatura mexicana moderna (México, 1974), pp. 123-143. 
sensaciones. Con una acertada mirada retrospectiva, escribe Torres Bodet sobre el sensualismo de López Velarde ${ }^{28}$ :

... los jóvenes hallaron en él las cualidades y los defectos que faltaban a González Martínez. Sus sentidos, ante todo, de espléndida virginidad natural y, sin embargo, refinada y exquisita... Y, con sus sentidos, un estremecimiento espiritual, menos metódico y grave que el de González Martínez, más espontáneo, en cambio, y más conmovedor...

Con la razón pura no se puede versificar, y, precisamente, los leves reparos que López Velarde hace a González Martínez y Alfonso Reyes se deben a un exceso de intelectualismo que él percibe en ambos. También la poesía lopezvelardiana refleja un criollismo genuino y decoroso, sin tropicalismos de ninguna clase, que apunta hacia la médula de la patria. Defiende en varias ocasiones ese concepto criollista, y de una manera explícita la prosa "Novedad de la patria» es una introducción imprescindible a las realizaciones de «La suave patria». Cuando López Velarde se exterioriza en la circunstancia es para asomarse al mismo tiempo a su propia alma, y, como se ha dicho, su nacionalismo es una actitud estética, formando parte integral de ese amor a la realidad de todos los días, que espera su salvación por la mirada del poeta ${ }^{29}$.

Sin embargo, es en su idioma poético donde López Velarde revela su máxima originalidad. Las audacias linguiísticas son auténticas en él, y repitamos otra vez la frase que resume su actitud ante la lengua: «Yo anhelo expulsar de mí cualquier palabra, cualquier sílaba que no nazca de la combustión de mis huesos ("La derrota de la palabra»). El lector tiene la sensación de que el poeta mexicano, como Lugones, también quería medirse con todas las palabras y todas sus posibilidades de significado. Se entretiene con la lengua; estiliza y complica, retuerce y aprieta la expresión; funde lo prosaico y lo poético dando nuevas tensiones al lenguaje de la poesía. Hasta los desechos le proporcionan sorprendentes modos de decir cuando funde con to trascendente lo ordinario en original síntesis:

Mi carne es combustible y mi conciencia parda;

efímeras y agudas refulgen mis pasiones cual vidrios de botella que erizaron la barda del gallinero, contra los gatos y ladrones.

(«El perro de San Roque», de $E l$ són del corazón)

\footnotetext{
${ }^{28}$ Jaime Torres Bodet, «Perspectiva de la literatura mexicana actual, 1915-1928», en Contemporáneos, II, núm. 4 (septiembre 1928), pp. 9-10.

${ }^{29}$ Octavio Paz, «El camino de la pasión», en Cuadrivio (México, 1965), p. 86.
} 
Hasta la aproximación de términos tan dispares como el teléfono y náyades sin duda constituyen un elemento sorpresivo: «Tardes en que el teléfono pregunta / por consabidas náyades arteras» («Tierra mojada», de Zozobra). El adjetivo tomado de las más variadas fuentes modernas que precisa e individualiza es un arma constante de su estilo, sirviendo además de elemento intensificador de su expresión. Veamos en rápida nómina algunos ejemplos: hidráulica querella, viudo oscilar del trapecio, oxidada la voluntad, látigo incisivo de tus cejas. También el adjetivo suele revestirse de una inesperada movilidad: la cristalina nostalgia de la fuente, el relámpago verde de los loros, un encono de hormigas en mis venas voraces, un enamorado mausoleo, la redecilla de medrosas venas, / como una azul sospecha / de pasión. Tal vez los procedimientos de este tipo llegan a resumirse en el conocido poema «El retorno maléfico», donde se leen fórmulas expresivas como párpados narcóticos, dramáticos faroles y otras dignas de señalarse. Es excusado decir que ciertos adjetivos en la poesía de López Velarde son portadoras de metáforas, al aplicarse a un sustantivo, que, según el pensamiento conceptual, no admitiría esa caracterización.

Así es que Ramón López Velarde no sólo cierra el modernismo en México, resumiendo un proceso que comenzó con Gutiérrez Nájera, sino que también abre caminos para el futuro. En sus mejores composiciones («Día 13», «Todo», «Tierra mojada», «Hormigas», «La última odalisca», «El candil», «Gavota», «Treinta y tres» y media docena más), la poesía deja de ser anécdota y descripción: es, en cambio, una honda aventura espiritual, desde fuera hacia dentro, donde, en su conciencia, están pasando graves cosas conflictivas y hasta trágicas. López Velarde, sin embargo, sabe separarse de sí mismo (¿lo aprendió en Laforgue?), y ese acto contemplativo se realiza en las confidencias oblicuas o hechas al margen, de tono conversado e íntimo, y en las subidas o caídas de tono. Es decir, en ese desdoblamiento se enfrenta a la realidad y a su persona con una actitud esencialmente irónica ${ }^{30}$. Si en Lugones predomina lo burlesco y lo festivo, es en el escritor mexicano algo mucho más hondo: un sentido moral que matiza a veces su expresión irónica. No inventa mundos como Huidobro, sino que, por el contrario, busca las raíces de làs cosas y trata de descubrir como realmente son. Cerremos estas breves páginas con un párrafo de Villaurrutia, que resume admirablemente el alcance de la obra de López Velarde ${ }^{31}$ :

${ }^{30}$ Son excelentes las páginas de Paz sobre la ironía en López Velarde y la naturaleza del poema moderno, ibíd., pp. 74-76.

${ }^{31}$ Xavier Villaurrutia; «Ramón López Velarde», en Textos y pretextos (México, 1940), p. 36. 
En la poesía mexicana, la obra de Ramón López Velarde es, hasta ahora, la más intensa, la más atrevida tentativa de revelar el alma oculta de un hombre; de poner a flote las más sumergidas e inasibles angustias; de expresar los más vivos tormentos y las recónditas zozobras del espíritu ante las incitaciones del erotismo, de la religiosidad y de la muerte.

\section{José Juan Tablada}

Todo depende del concepto que se tenga del arte. Hay quien lo cree estático y definitivo; yo lo creo en perpetuo movimiento y en continua evoltición como los astros y como las células de nuestro cuerpo mismo. La vida universal puede sintetizarse en una sola palabra: movimiento... (J. Juan Tablada, 1919).

Tablada se formó en el modernismo y en los cenáculos de la Revista Moderna, cuya fundación se le debía en gran parte, e inicia en México la vertiente decadentista del modernismo al publicar poemas como «Misa negra» y «Onix», ambos de 1893 e incorporados luego a El Florilegio. Años después, en 1919, Tablada se adelanta a su tiempo y se convierte en el primer vanguardista de México, recogiendo ecos de todas las revoluciones artísticas europeas de aquellos tiempos convulsivos. En constante evolución, curioso del futuro e inquieto, es el heraldo de los nuevos evangelios. Actualidad y diversidad. Cree, firmemente, en el perpetuo moviminto del arte; su espíritu múltiple se lanza al culto de todas las novedades; ávido de renovación, experimenta una prisa casi juvenil de probarlo todo. De ahí su grandeza y su debilidad. De paso, en 1923 fue proclamado en México el poeta más representativo de la juventud. Ha quedado muy atrás su primera fase, caracterizada por un erotismo fúnebre y macabro, de índole mística y tono blasfematorio. Buscaba adrede le frisson nouveau de Baudelaire y seguía las huellas de Huysmans, maestro de las sensaciones exquisitas. Pronto, con el transcurrir del tiempo, el poeta artífice se olvida de los paraísos artificiales; se aleja de la bohemia artística y del modernismo exterior, versallesco y exotista, para dar los primeros pasos hacia la eclosión del vanguardismo ${ }^{32}$. Marca la época de transición el libro Al sol y bajo la luna (1918), que lleva Prólogo en verso del muy admirado Lugones (Tablada le había consagrado en 1898 unas páginas críticas rebosantes de elogios y publicadas en la Revista Moderna, y, por su parte, Lugones dedica a Tablada «Los doce gozos») y al cual pertenece

${ }^{32}$ Me ocupé detenidamente de los antecedentes modernistas del poeta en otra parte: «El primer José Juan Tablada: modernismo y decadentismo», en Homage to Irving A. Leonard (Michigan State University, 1977), pp. 181-196. 
el poema de antología «Quinta Avenida», cuyos últimos versos reproduzco ahora en su forma retocada:

¡Mujeres fire-proof a la pasión inertes, hijas de la mecánica Venus made in America; de nuestra fortaleza, la de las cajas fuertes, es el secreto... idéntica combinación numérica!

En 1919, como ya se dijo, Tablada publica Un día, poemas sintéticos a la manera de los haikais japoneses, e introduce así con singular fortuna esta breve forma en la poesía de habla española. Muchos poetas de alta categoría, tanto americanos como peninsulares, se aprovecharon de esta modalidad poética, dirección felizmente continuada por Tablada en otro libro posterior, El jarro de flores (1923), en cuyo Prólogo el autor se complace en haber iniciado el haikai y explica: «... aunque no fuese sino como una reacción contra la zarrapastrosa retórica, ... el haikai, de floral desnudez, no necesita búcaros. Por esencia, es justo vehículo del pensamiento moderno; tema lírico puro, adámico como la sorpresa y sabio como la ironía». Se ha miniaturizado el modernismo, y la poesía se reduce a la imagen sintética e instantánea. Así se gana la poesía en concisión y se combate una retórica inútil. Leamos unos ejemplos de $E l$ día:

\section{LA TORTUGA}

Aunque jamás se muda a tumbos, como carro de mudanzas, va por la senda la tortuga.
LA LUNA

Es mar la noche negra; la nube es una concha; la luna es una perla.

\section{EL PAVO REAL}

Pavo real, largo fulgor, por el gallinero demócrata pasas como procesión...

Y otros tres de El jarro de flores:

EL BURRITO

Mientras lo cargan sueña el burrito amosquilado en paraísos de esmeralda...
UN MONO

El pequeño mono me mira... ¡Quisiera decirme algo que se le olvida!

\section{IDENTIDAD}

Lágrimas que vertía

La prostituta negra,

blancas... icomo las mías! 
El haikai suele ser un instante de súbita iluminación e intuición lírica basada en una realidad conocida, aunque vista de manera insólita o sorprendente. En sus poemitas sugestivos Tablada no sólo recoge una forma, sino también una disciplina estética, cumpliendo con el programa expresado en verso en el Prólogo a El día: «Arte, con tu áureo alfiler / las mariposas del instante / quise clavar en el papel.» El poema ha sido visualizado y queda olvidada la poesía de confesión o meditación. El japonismo de Tablada obedece ya a otros fines menos exóticos.

Finalmente, en Caracas aparece el breve libro Li-Po y otros poemas (1920), compuesto casi totalmente de poemas ideográficos, que se parecen mucho a los caligramas que elaboraba Apollinaire hacia las mismas fechas. Quizá conviene advertir aquí que Tablada había residido en París (19111912), donde conoció de primera mano la eclosión de los ismos experimentales de los pintores y escritores. Así se dio una forma visual y gráfica a sus composiciones poéticas, lo que le acerca evidentemente a un aspecto de la vanguardia europea. En esta misma colección figura su conocido poema simultáneo "Nocturno alterno», en que una poesía se sobrepone a otra, fundiéndose las dos, bajo la Luna, que es igual en Nueva York que en Bogotá.

Que se me permita un breve paréntesis. Por muchos años, Tablada fue un poeta prácticamente desconocido por varias razones: sus largas ausencias de la patria y el número reducido de los ejemplares de sus libros principales. Ese olvido fue corregido en gran parte por su fino y fiel amigo, el Abate de Mendoza, autor de páginas imprescindibles sobre el poeta ${ }^{33}$. En días posteriores, el redescubrimiento del poeta se debe a la fascinación que ejerce sobre Octavio Paz, cuyo estudio «La estela de José Juan Tablada» (Las peras del olmo [México, 1957], pp. 76-85) inicia una serie de comentarios, siempre esclarecedores, publicados en distintos lugares (Poesía en movimiento y El signo y el garabato). En ellos, Paz exalta las cualidades de sorpresa y humor, aventura y viaje, cosmopolitismo y curiosidad encontradas en la obra de Tablada posterior a 1919. Recordemos de paso un anticipo de Villaurrutia, que apreció la tentativa del poeta mayor. En su conferencia «La poesía de los jóvenes de México» reconoce la gran importancia que tuvo hacia aquellos años la poesía grave de González Martínez. Algo faltaba: una mayor libertad y un panorama estético

${ }^{33}$ Aunque falta el Prólogo a la primera antología de los versos de Tablada (Los mejores poemas de José Juan Tablada [México, 1943]), se recogen de José María González de Mendoza dieciséis breves notas en su libro de publicación póstuma: Ensayos selectos (México, 1970), pp. 114-198. 
más amplio. Según Villaurrutia, el que primero sacudió en México la inmovilidad del verso fue el inquieto e inquietador Tablada ${ }^{34}$.

Tablada y López Velarde, diecisiete años menor, eran amigos y unidos por los mismos anhelos literarios. En efecto: López Velarde fue presentado a los lectores capitalinos desde las páginas de El Mundo Ilustrado (7 de junio de 1914), mediante una crónica de Tablada. Dos textos del poeta más joven sobre su amigo son especialmente significativos: «Poesía y estética» (1917) y «José Juan Tablada» (1920). En 1917 encontró en el lenguaje de Tablada la razón de su novedad, y lo considera «una de las más severas aristocracias» de la poesía mexicana. En el segundo comentario, de mayor profundidad crítica, comienza por negar la frivolidad de Tablada e insiste en la auténtica emoción que no deja de palpitar en sus versos. Se admite que $A l$ sol y bajo la luna tiene desniveles, pero López Velarde califica a Un día de «libro perfecto», y señala en él la presencia de dos virtudes, que exaltaba siempre dondequiera que las descubría: «médula vital» y «la victoria que las modalidades expresivas consiguen sobre la crasa dicción de la ralea». López Velarde percibe en Tablada «un poeta de arte eximio» y elogia su exploración de nuevas rutas artísticas, rechazando la idea de algunos de que tal tentativa es mera extravagancia. El colofón debido: el «Ex Voto» o «Retablo a la memoria de Ramón López Velarde», uno de los más sentidos poemas de Tablada, de veras afligido por la prematura desaparición del poeta zacatecano.

Ahora bien: dentro del presente contexto es de singular importancia un intercambio de cartas entre López Velarde y Tablada en 1919, documentos sobremanera pertinentes para el estudio de esos años de transición. El 18 de julio, cuando Tablada residía en Caracas, le dirige López Velarde una carta que constituye un texto revelador, en el cual expresa una actitud de reserva y de duda ante la poesía ideográfica que entonces ensayaba Tablada. He aquí una parte de ese documento ${ }^{35}$ :

... Mi actitud, en suma, es de espera. Hasta hoy, lo ideográfico me interesa, más que por sí mismo, por usted que lo cultiva. Desde que conocí lo de Apollinaire, se me quedó la impresión de algo convencional, ... Hoy por hoy, dudo con duda grave de que la poesía ideográfica se halle investida de las condiciones serias del arte fundamental. La he visto como una humorada, capaz, es claro, de rendir excelentes frutos si la ejercita un hombre de la jerarquía estética de usted.

${ }^{34}$ Xavier Villaurrutia, «La poesía de los jóvenes de México», en Obras (México, 1966), pp. 825-826.

${ }^{35}$ Ramón López Velarde, Poesías, cartas, documentos e iconografía, Prólogo y recopilación de Elena Molina Ortega (México, 1952), pp. 75-77. 
Las cautas palabras de López Velarde son claras y me eximen de comentario. La respuesta de Tablada, escrita probablemente en el verano o el otoño de 1919, no se hace esperar, y para nuestros fines aquí, se trata de un texto imprescindible ${ }^{36}$. En él Tablada hace una defensa y exégesis de sus procedimientos poéticos, $y$, para abreviar, transcribo solamente una pequeña porción de tan significativa carta literaria, en la cual se refiere a sus más recientes poemas:

... son un franco lenguaje; algunos no son simplemente gráficos, sino arquitectónicos... Y todo es sintético, discontinuo y, por tanto, dinámico; lo explicativo y lo retórico están eliminados para siempre; es una sucesión de estados sustantivos; creo que es poesía pura... La ideografía tiene, a mi modo de ver, la fuerza de una expresión «simultáneamente lírica y gráfica», a reserva de conservar el secular carácter ideofónico. Además, la antigua poesía, dejando los temas literarios en calidad de «poesía pura», como to quería Mallarmé. Mi preocupación actual es la síntesis, en primer lugar porque sólo sintetizando creo poder expresar la vida moderna en su dinamismo y en su multiplicidad (p. 612).

Estamos ya en otro clima. Los refinamientos de sus primeros libros han sido postergados: frente al poema con argumento busca formas dibujadas y se empeña en la eliminación de todo lo discursivo, lo cual le permitirá captar en su poesía la multiplicidad de la vida moderna ${ }^{37}$. Y lo llama Octavio Paz: «... un hermano menor de Vicente Huidobro. $Y$ algo más: Tablada, gracias a unos cuantos poemas, es uno de nuestros verdaderos contemporáneos» ${ }^{38}$, extendiendo las fronteras de la poesía. Para concluir, basta decir que, en la dinámica de los movimientos literarios, los cuatro poetas estudiados enriquecen una tradición al mismo tiempo que cada uno, a su modo y en grado distinto, señala una apertura hacia el futuro. Su obra, pues, constituye un puente destinado a unir dos épocas históricas en el desarrollo de la poesía hispanoamericana.

${ }^{36}$ Esta carta se publicó en El Universal Ilustrado, núm. 132 (13 de noviembre de 1919), p. 23, y fue totalmente desconocida hasta que yo me ocupé de ella, primero en el ya citado artículo sobre Tablada y López Velarde, escrito en 1961 (pp. 610-613).

${ }^{37}$ Según Alfredo A. Roggiano («José Juan Tablada: espacialismo y vanguardia», en Hispanic Journal, I, núm. 2 [Primavera de 1980], pp. 47-55), «... más que un precursor o vanguardista pleno, Tablada es un experimentador con 'otro tipo de poesía': la sintética, ideográfica, pictográfica, caligráfica espacial, por donde se podría ir al concretismo... Tablada no inició en lengua española, como lo hizo Huidobro, un nuevo sentido del poema según una nueva concepción de la imagen poética: la creacionista, si bien siguiendo una línea ya experimentada en la lengua francesa por Saint-Paul Roux, Mallarmé (en parte) y Pierre Reverdy... Pero Tablada es el más curioso renovador poeta hispanoamericano situado en la transición del modernismo. a la vanguardia...) (p. 54).

${ }^{38}$ Octavio Paz, El signo y el garabato (México, 1973), p. 189. 
